\title{
ORGANIZATION OF THE CYSTS IN BEE (HYMENOPTERA, APIDAE) TESTIS: NUMBER OF SPERMATOZOA PER CYST
}

\author{
Carminda da Cruz-Landim ${ }^{1}$
}

\begin{abstract}
The morphology of the cyst cells in Apis mellifera Linné, 1758, Scaptotrigona postica Latreille, 1804, and Melipona bicolor bicolor Lepeletier, 1836 testis, as well as the average number of spermatic cells are reported. The data indicates a supporting and nourrishing role of the cyst cells to the developing cystocytes. The counts of immature spermatozoa in the cysts show an average of $202.8 \pm 21.2$ spermatozoa for A. mellifera, 117.4 \pm 8.68 for $S$. postica and $88.8 \pm 15.57$ for $M$. bicolor, which predict the occurrence of 8 mitotic cycles in the cystocytes of $A$. mellifer $a$ and 7 in the meliponines, considering that only one spermatozoom originates of each final spermatogonium.
\end{abstract}

KEYWORDS. Cyst cell, cell number average, testis, bees.

\section{INTRODUCTION}

At the distal end of each insect testis tubule or follicle is the germarium, in which the germ cells divide to produce spermatogonia. These indifferentiated germ cells, known as primary spermatogonia divides mitotically into a group of secondary spermatogonia, the secondary spermatogonia who become individually encapsulated by a somatic cell, the cyst cell. Later the cyst cell will form the envelope to the cyst formed by the spermatogonia mitotic division. Within the cyst the secondary spermatogonia undergo a series of sucessive synchronous mitotic division during the multiplication period, and arise the constant, species specific, numbers cystocytes (TiHen, 1946; CoOPER, 1950; Hannah-Alava, 1965; Meyer, 1968; Courot et al., 1970; Kurokawa \& Hihara, 1976; Lindsley \& Tokuyasu, 1980; Oguma \& Kurokawa, 1984), which after meiosis will originate the spermatids, and finally the spermatozoa.

The number of sperm ultimately present in a cyst, therefore depends, primarilly on the number of spermatogonial premeiotic divisions (Oguma \& KuROKAwa, 1984; OGuma et al., 1987).

Frequently after spermiogenesis, the sperm of the same cyst remain together for a variable lapse of time, as a bundle. The number of spermatozoa in the bundle tends to be species specific and according to VIRKKI $(1970,1973)$ specialized insects tend to have less spermatozoa per bundle than the more primitive insects.

Although generally the mitotic divisions whithin the cyst are synchronous, in Drosophila (Diptera) they are asynchronous and the number of spermatocytes per cyst varies (LIEBRICH, 1984). The expected number may also be changed in atypical types of spermatogenesis as that occurring in bees (Meves, 1907; Hodge \& Kessel, 1968; CruZLANDim \& Beig, 1980; CRUZ-Landim et al., 1980), because of the males haploidy.

The cyst cells may supply nourrishment to the developing sperm. In some Diptera according to WeNSLER \& REMPEL (1962), there appear three types of nutritive cells, which function sequentially in spermatogenesis. The first is the "cyst cells" which form the monolayer around each primitive germ cell. The second type would originate from spermatogonia that do not suffer spermatogenesis and them differentiate into trophocytes.

1. Departamento de Biologia, Instituto de Biociências, Universidade Estadual Paulista (UNESP), Caixa Postal 199, 13506-900, Rio Claro, SP, Brasil. 
The latter is an elongated cell located among the cystocytes. CHAPMAN (1998) reports in some insects the presence of irregular cells named trophocytes, scattered amongst the cysts, that may correspond to this last cell type.

In some insects at one given stage of the final spermiogenesis, the heads of the immature spermatozoa become embedded in the cyst cells cytoplasm (CARSON, 1945; Bonhag \& Wick, 1953; Wilde, 1964; Cruz-Landim \& Ferreira, 1981; Gillot, 1998). In Myogrillus sp. (Orthoptera) the cyst cells are large, with nuclei of irregular contours and many superficial infoldings where the spermatozoa heads are lodge. The lysosomal granules and digestive vacuoles present in this cell cytoplasm suggest its role in the engulfment and digestion of the maturing spermatozoa debris (CRUZ-LANDIM \& FERREIRA, 1981).

The aims is to describe the cyst organization and the sperm numbers in three different species of bees, taking in account the absence of meiosis due to the haploid condition of the Hymenoptera males.

\section{MATERIAL AND METHODS}

The bee species studied were Apis mellifera Linnaeus, 1758, Scaptotrigona postica Latreille, 1804 and Melipona bicolor bicolor Lepeletier, 1836, all raised in the Department of Biology (UNESP, Rio Claro, SP) apiary.

Brown eyed, male pupae, have their testis dissected and fixed for TEM in Karnowisky in $0.1 \mathrm{M}$ Na Cacodylate buffer, $\mathrm{pH} 7.2$ during $2 \mathrm{~h}$ at room temperature. After washing in the buffer the testis were post fixed in $1 \%$ osmium tetroxide in the same buffer. The dehydration was carried out in acetone increasing concentration series and the embedding in Epon-Araldite resin. Thin sections were stained with uranyl acetate and lead citrate and examined with TEM. Thick sections of same material were stained with $1 \%$ toluidine blue and examined with light microscope.

The counts of sperm cells in the cyst were made in three different specimens of each species totallizing 10 cysts for each species. The cyst used containned immature spermatozoa and were cut crossward.

\section{RESULTS AND DISCUSSION}

The cyst in the studied bees, is formed by the result of divisions of a secondary spermatogonia, generally named cystoblast. Each cyst, therefore, contains a certain number of spermatogonia or cystocytes according to the maturation phase. Since the beginning the set of cystocytes are enclosed by cyst cells in such a way that the cyst become filled with piramidal cells with their bases against the cyst wall and their inner ends converging to the center of the cyst forming a rosette-like structure (figs. 1-3).

The cyst cells are very flat and sometimes contain granules that are stained by toluidine blue (fig. 2). They are rich in mitochondria and glycogen scattered in the cytoplasm (figs. 2,4). Apparently only one cyst cell makes all the contour of the cyst, in such a way that it has an enlarged region of the cytoplasm where the nucleus is, and thin long prolongations that envelope the cystocytes (figs. 3, 4). The nucleus is large, with disperse chromatin and a well structured nucleolus. Pieces of what seem to be larger cells (fig. 1) also rich in mitochondria and glycogen (fig. 5) may be found in the TEM preparations, scattered amongst the cystocytes and was considered as part of trophocytes.

Although the cyst cells around the maturing spermatids seem to have increased cytoplasm it do not displays pseudopodia or other cytoplasmatic projections toward the 
spermatozoa in the cyst lumen (fig. 5). The spermatozoa produced in the cyst remain together until leave the seminiferous tubule, forming bundles (figs. 6, 7).

The numbers found for S. postica and M. bicolor bicolor are suggestive of 7 cycles of mitosis before the meiosis and for $A$. mellifera of 8 cycles (tab. I).The aberrant meiosis that takes place by the end of the multiplication phase, produce two spermatids (CRuz-Landim \& Beig, 1980; CRUz-Landim et al., 1980). Only the large one, with complete set of cytoplasmatic organelles gives rise to a spermatozoom. Therefore the number of immature spermatozoa per cyst will be the same of first spermatocytes.

Nevertheless if the results of KERR \& SiLveIRA (1974) was to be taken in account, let say, the two spermatids originating spermatozoa, the meiosis will duplicate the number of cells by cyst and correspondently the number of pre-meiotic cycles of division decreases one point (6 cycles for $S$. postica and M. bicolor bicolor and 7 cycles for A. mellifera). This point cannot be clarified because although it seems improbable that a spermatid without mitochondria and Golgi (fig. 5) could originate a spermatozoom, signals of this cell degeneration were not observed during spermatogenesis. One possibility is that they fuse together to produce the trophocyte, as suggested by WENSLER \& REMPEL (1962). However the fragment of cells seem with TEM scattered amongst the cystocytes (figs. 3, 4) and interpreted as pieces of trophocytes is rich in mitochondria and glycogen, these components should arised posterior to fusion, from undected precursors. These results show that three type of somatic cells seem to be present into the seminiferous tubule of bees: 1) the cyst cells around the cystocytes; 2) the cells amongst the cystocytes, maybe corresponding to the elongated cell described by WeNSLER \& REMPEL (1962); 3) cells scattered amongst the cysts (fig. 1 ).

The mature spermatozoa arised in the cyst, when yet in the testis tubules remain together forming a bundle (figs. 6,7). Nevertheless it is difficult to isolate, at same time, the bundles and separate suficiently the spermatozoa of one single bundle, from another in order to count the spermatozoa without mixing cells of several bundles. The greatest number obtained in tentative counts on A. mellifera was 38 which will correspond to 6 cycles of mitosis if encreasing number of cells were promoted by meiosis.

Although inconclusive as the number of cell mitosis during multiplication phase is concerned, the present results show that in bees the cyst cell mantain the cystocytes together until the complete maturation of the spermatozoa in the testis and that the spermatozoa formed in the same cyst leave the testis tubules as bundles. Also it is showed that in the studied bees the cyst cell may furnish nourishment to the sperm, as is suggest by glycogen presence, but do not have any function in the phagociting of the spermatids debris.

Table I. Sperm cell numbers in bee testis cysts.

\begin{tabular}{lrrrrrrrrrrrrr}
\hline & \multicolumn{110}{c}{ Cysts } \\
\cline { 2 - 14 } Species & 1 & 2 & 3 & 4 & 5 & 6 & 7 & 8 & 9 & 10 & X & SD \\
\hline & 217 & 227 & 206 & 180 & 222 & 180 & 170 & 206 & 228 & 192 & 202.8 & \pm 21.2 \\
Apis mellifera & 120 & 114 & 107 & 127 & 106 & 126 & 106 & 128 & 120 & 120 & 117.4 & \pm 8.68 \\
Scaptotrigona postica & 120 & 114 & 75 & 75 & 88 & 74 & 100 & 75 & 69 & 112 & 106 & $88.8 \pm 15.57$ \\
Melipona b. bicolor & 114 &
\end{tabular}



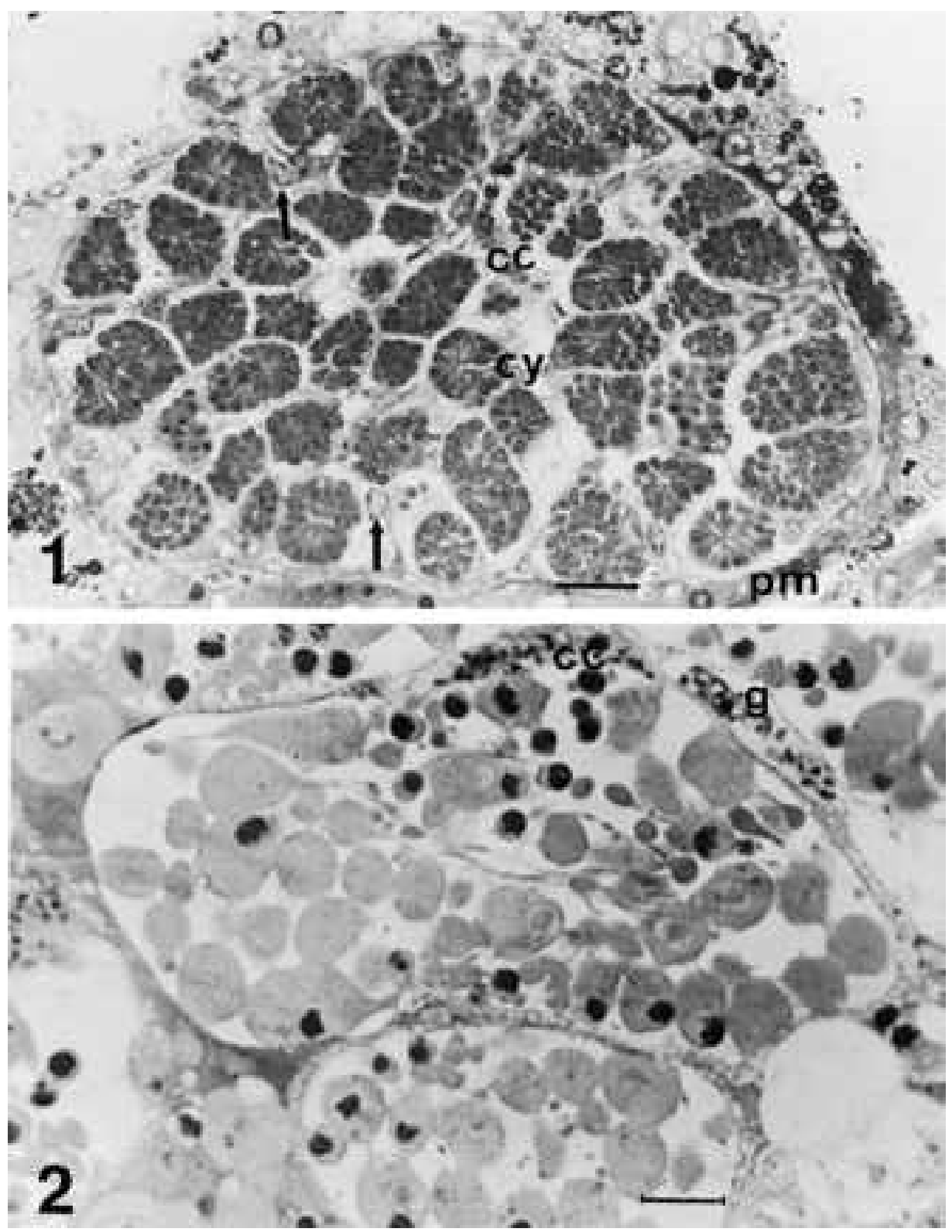

Figs. 1, 2. Light micrographs of sections of the seminiferous tubules of Apis mellifera stained with toluidine blue: 1 , seminiferous tubule showing several cysts (cy) enveloped by cyst cells (cc). Notice some cells scattered amongst the cysts (arrows), barr $=50 \mu \mathrm{m} ; 2$, cyst containg spermatids showing cyst cell containing granules in the cytoplasm ( $\mathrm{pm}$, peritoneal membrane), barr $=20 \mu \mathrm{m}$. 

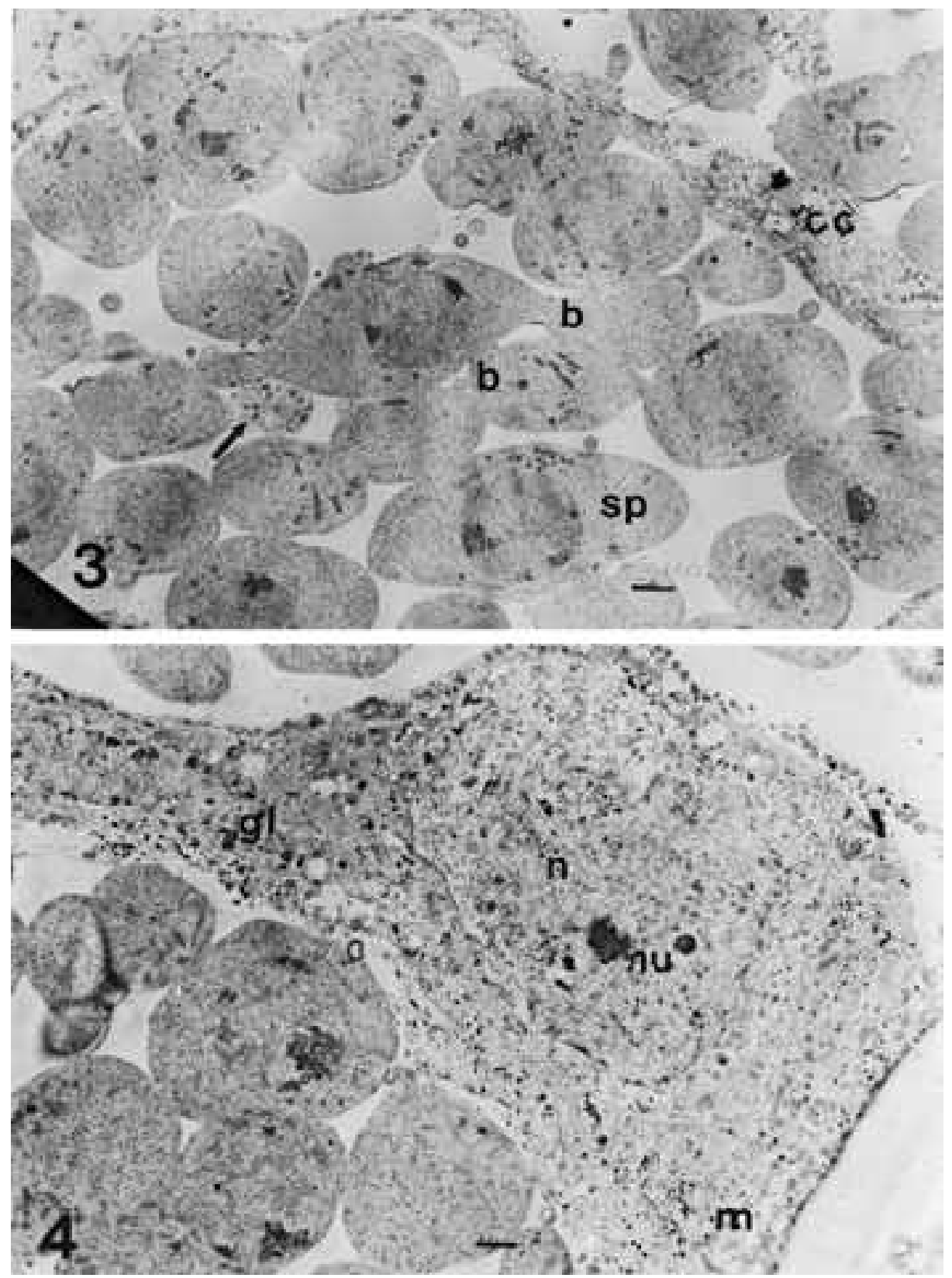

Figs. 3, 4. TEM micrographs of Apis mellifera testis: 3, flat cyst cell (cc) around cystocytes (sp). Notice cell pieces amongst the cystocytes (arrow), bar $=5 \mu \mathrm{m} ; 4$, nucleus (n) region of the cyst cell, showing mitochondria $(\mathrm{m})$ and glycogen $(\mathrm{gl})$ (b, intercellular bridges; nu, nucleolus), barr $=1 \mu \mathrm{m}$ 

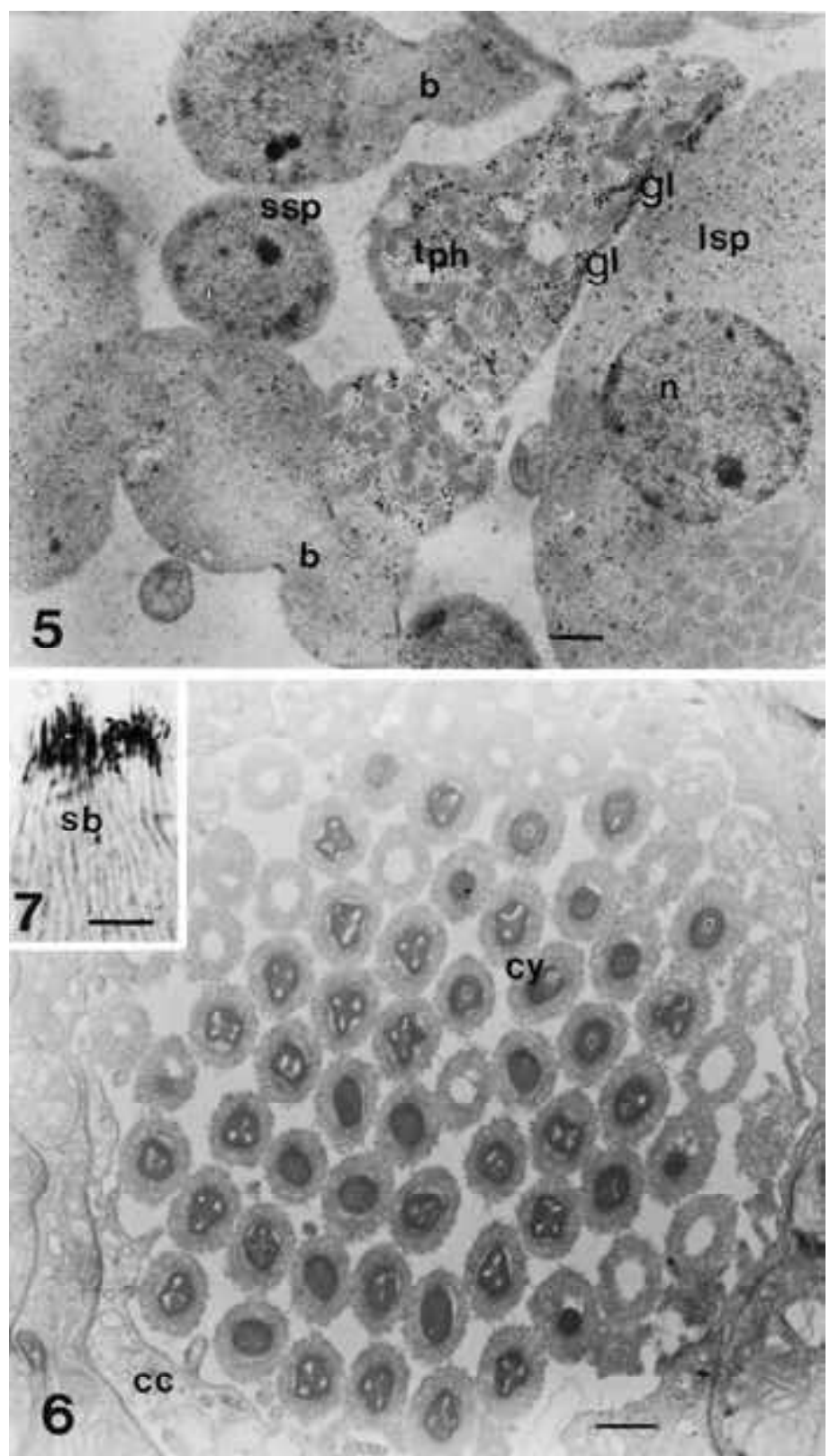

Fig. 5-7. TEM micrograph Apis mellifera: 5, trophocyte (tph) fragments containing glycogen (gl) into the cyst, barr $=1 \mu \mathrm{m}$. Melipona bicolor bicolor testis: 6 , a cross section of a cyst (cy) containing immature spermatozoa, barr=1 $\mu \mathrm{m} ; 7$, a light micrograph of a sperm bundle (sb) (b, intercelular bridge; cc, cyst cell; lsp, large spermatid; n, nucleus; ssp., small spermatid). 
Acknowledgments. To FAPESP (Process 99/00719-6) and CNPq (Process 520.566/95-5).

\section{REFERENCES}

Bonhag, G. P. \& Wick, J. R. 1953. The functional anatomy of the male and female reproductive systems of the milkweed, Oncopeltus fasciatus (Dallas)(Heteroptera: Lygaeidae). J. Morph., New York, 93:177-283.

Carson, H. L. 1945. A comparative study of the apical cell of the insect testis. J. Morph., New York, 77: 141-155.

Chapman, R. F. 1998. The Insects: structure and function. Cardiff, Cambridge University 770 p.

CoOper, K. W. 1950. Normal spermatogenesis in Drosophila.In:Demerec, M. ed. Biology of Drosophila. New York. p. 1-61.

Courot, M.; Hochereau-de-Reviers, M. T. \& Ortavant, R. 1970. Spermatogenesis. In: Johnson, A. D., Gomes, W. R. \& Vandemark, N. L. The Testis. New York, Academic. v. 1, p. 339-432.

Cruz-Landim, C. \& Beig, D. 1980. An electron microscopic study of spermatogenesis in the drone of Scaptotrigona postica (Hymenoptera, Apidae). Int. J. I. Reprod., Rehowot, 2:271-283.

Cruz-Landim, C.; Beig, D. \& Silva de Moraes, R. L. M. 1980. The process of differentiation during spermatogenesis in bees (Hymenoptera, Apidae). Caryologia, Florença, 33:1-15.

Cruz-Landim, C. \& Ferreira, A. 1981. Studies on the fine structure of cyst cells and its relationships with the spermatids on Myogrillus sp. (Orthoptera). Revta bras. Biol., São Carlos, 41:401-406.

Gillot, C. 1998. Accessory Sex Glands, Arthropoda-Insecta. In: AdiYOdi, K. G. ed. Reproductive Biology of Invertebrates. New York, John Wiley \& Sons. v. 3, p. 39-47.

Hannah-Alava, A. 1965. The premeiotic stages of spermatogenesis. Adv. Genet., San Diego, 13:157-226.

Hoage, T. R. \& Kessel, R. G. 1968. An electron microscope study of the process of differentiation during spermatogenesis in the drone honey bee (Apis mellifer $\mathrm{L}$.), with special reference to centriole replication and elimination. J. Ultrastruct. Res., Orlando, 24:6-32.

Kerr, W. E. \& Silveira, V. 1974. A note on the formation of honeybee spermatozoa. J. Apic. Res., Cardiff, 13:121-126.

KurOKaWA, H. \& Hihara, F. 1976. Number of first spermatocytes in relation to phylogeny of Drosophila (Diptera: Drosophilidae). Int. J. Insect Morphol. \& Embryol., Kidlington, 5:305-310.

Liebrich, W. 1984. Premeiotic divisions of gonial cells are differently regulated in males in females of Drosophila. Int. J. Invertebrate Reproduct. \& Develop., Rehovot, 7:369-371.

Lindsley, D. L. \& Tokuyasu, K. T. 1980. Spermatogenesis. In: Ashbumer, M. \& Wright, T. R. eds.. The Genetics and Biology of Drosophila. New York, Academic. v. 2d, p. 225-294.

Meves, F. 1907. Die Spermatocytenteilungen bei der Honigbiene (Apis mellifera L.), nebst Bemerkungen über Chromatin-reduktion. Arch. mikrosk. Anat. EntwMech., Berlin, 70:414-491.

MeYer, G. F. 1968. Spermiogenesis in normalen und 4-defizienten Mänchen von Drosophila melanogaster und D. hidei. Z. Zellforsch. mikrosk. Anat., Berlin, 84:141-175.

Oguma, Y. \& Kurokawa, H. 1984. The least cell number of first spermatocytes per cyst found in Drosophila kanekoi. Jap. J. Genet., Tokyo, 59:263-265.

Oguma, Y.; Kurokawa, H. \& Kusama, T. 1987. Number of primary spermatocytes in the Drosophila immigrans (Sturtevant) group (Diptera: Drosophilidae). Int. J. Insect Morphol. \& Embryol., Kidlingston, 16:85-89.

TinEN, J. A. 1946. An estimate of the number of cell generations preceding sperm formation in Drosophila melanogaster. Am. Nat., Chicago, 80:389-392.

VIRKKI, N. 1970. Alticial beetles with 128 sperm cell per bumdle. J. Agric. Univ. P. Rico, Chicago, 54:586-587. - 1973. Evolution of sperm cell number per bundle in insects. An. Es. nac. Cienc. biol. Méx., México, 20:23-54.

WeNSLER, R. I. D. \& ReMPeL, J. G. 1962. The morphology of the male and female reproductive systems of the midge, Chironomous plumosus L. Can. J. Zool., Otawa, 40:199-229.

WiLde, J. 1964. Reproduction. In: Rockstein, M. ed. The physiology of Insecta. Otawa, Academic. v. 1, p. $10-58$.

Recebido em 08.02.2001; aceito em 06.09.2001 